\title{
Is Sri Lanka's marine products exports competitive? Analysis of fisheries exports of Sri Lanka
}

\author{
Gihan L. Dahanayaka ${ }^{1}$ and P.Sivarajah ${ }^{2}$ \\ 'National Aquatic Resources Research and Development Agency, Crow Island, Colombo 15, Sri Lanka \\ ${ }^{2}$ Department of Agricultural Economics, Eastern University, Chenkalady, Sri Lanka
}

\begin{abstract}
Fish export industry in Sri Lanka has become a good source of foreign exchange earnings. The efficiency of the sector can be improved considerably through the development of its trade system. An attempt was made in this paper to determine the performance of fisheries sector trade, the degree of export diversity, the price competitiveness of fisheries product and the impact of fisheries export for the economic growth of the country. The present study is based on time series data pertaining to the period from 1995 to 2004. The data on value of export of fisheries product for Sri Lanka was collected from different volumes of External Trade Statistics reports. To study the composition of export of different fisheries products, percentage export value shares were calculated. The concentration rate of export fisheries products was estimated by using the Hirschman-Herfindhal Index. The Simpson Diversity Index was used to measure the diversity of exports of fisheries products. Export competitiveness of fisheries commodities was calculated by computing the Nominal Protection Coefficient (NPC). Results revealed that the compound growth rates of fisheries sector were 0.13 and 0.1 percent in terms of value of exports and quantity of exports respectively. The export diversification index fluctuated between 76 percent in 1995 and 68 percent in 2004. An examination of NPC for different fisheries products such as Prawns, Crabs and Lobsters indicated that all the goods were competitive internationally, because all the values were less than unity every year. A regression analysis confirms that there exists a statistically significant and positive association between exports and economic growth in Sri Lanka. If Sri Lanka aims to achieve a high rate of economic growth through promoting exports then it has to minimize the fluctuations in export earnings, maintain export competitiveness and promote exports.
\end{abstract}

Key words: Marine products, value of exports, Hirschman-Herfindhal Index, Nominal Protection Coefficient, Simpson Diversity Index.

\section{Introduction}

One of the most important manifestations of economic globalization is the expansion of international trade. The progressive liberalization of world trade through, the establishment of the World Trade Organization (WTO), however, has created opportunities for developing countries to access developed country markets more easily. In particular, recent efforts to reduce barriers to trade in agricultural and food products, including tariffs, quantitative restrictions and other trade barriers, through the Uruguay Round, provide opportunities for enhanced export performance for both traditional and non-traditional products (Henson and Loader, 2001).
The progressive liberalization of world trade has created opportunities for developing countries to become better integrated into the global trading system and to exploit their national and regional comparative advantages (Bathrick, 1998).

Evidence suggests that developing countries have a potential comparative advantage over developed countries in the production of agricultural and food products (Murphy \& Shleifer, 1997; Edwards, 1992; Milner, 1990). This applies to traditional products, as well as non-traditional products (Biggs et al., 1996). But the developing countries still face certain barriers to expand their world market share and ability to meet the demands of the world trading 
system, not only in terms of competitive prices but also for quality and safety standards (ESCAP, 1996).

Fish export industry in Sri Lanka has become a good source of foreign exchange earnings. As a foreign exchange earner, the share of fisheries sector in Sri Lanka export had increased from 1.51 percent to 2.61 percent during 1993 to 2000 , and thereafter started to decline. In 2004, foreign exchange earnings from export of fish and fishery products amounted to 9.4 billion Rupees, which is a 6 percent decrease, compared to the previous year earnings. Fish exports are also increasingly important to Sri Lanka relative to other agricultural commodities (Central Bank of Sri Lanka 2003; NARA 2003; EDB 2005).

This paper examines the temporal changes in the composition of exports of fisheries product, the performance of fisheries sector trade, the price competitiveness of fisheries products, and the impact of fisheries exports on economic growth.

\section{Materials and Methods \\ 1. Sources of Data}

The present study is based on time series data pertaining to the period from 1995 to 2004 . The data on value of export of fisheries product for Sri Lanka was collected from different volume of External trade statistics reports (Customs of Sri Lanka 1995-2002). The data on domestic wholesale prices of prawns, crabs and lobsters was collected from statistic division of Ministry of Fisheries and Ocean Resources. The data on international prices of fisheries products was collected from infofish trade news database. The data on CIF prices were collected from custom reports.

To study the composition of export of different marine products, percentage shares were calculated using the value of export and import data. The product concentration rate of marine product exports was estimated by using the Hirschman-Herfindhal Index (HHI), a commonly accepted measure of market concentration. It is calculated by squaring the market share of each firm competing in a market, and then summing the resulting numbers.
The HHI is calculated by the summing of squares of each product's market share within total marketed products. Higher values of the $\mathrm{HHI}$ are indicative of greater market concentration, and the values of the index range from 0 (highly unconcentrated) to 1 (single product concentration). The classification thresholds are listed below:

$\mathrm{HHI}<0.15$ indicates an un-concentrated market

\subsection{5 d" $\mathrm{HHI}<0.25$ indicates a moderately concentrated market}

HHI e" 0.25 indicates a highly concentrated market

$\mathrm{HHI}=\mathrm{PS}_{1}{ }^{2}+\mathrm{PS}_{2}{ }^{2}+\mathrm{PS}_{3}{ }^{2}+\mathrm{PS}_{4}{ }^{2} \ldots . .+\mathrm{PS}_{5}{ }^{2}$

Where,

PS $_{i}$-the share of values of exports of $i^{\text {th }}$ marine product $\mathrm{n}=$ Number of marine products exported

The Simpson Diversity Index (SDI) was used to measure the diversity of exports and imports of fisheries products. The value of this index also ranges between 0 and 1 , the greater the value, the greater the sample diversity, while lesser the value more concentration. The Simpson Diversity Index defined as follows,

Where;

$$
0=\frac{\Sigma n(n-1)}{N(N-1)}
$$

$n_{i}$ - Value of $i^{\text {ih }}$ product exported

$\mathrm{N}$ - Value of total products exported.

Diversification can lower earnings volatility if the country diversifies into products with price movements that are not strongly correlated with current exports (Love, 1986). However, if the new products are of lower value, there can be a tradeoff between greater stability and lower overall value of export earning. Consequently, diversification offers the potential but not the guarantee of greater export stability and higher export earnings.

Export competitiveness of fisheries commodities has been calculated by computing the Nominal 
Protection Coefficient (NPC). This is the ratio of Domestic Price to the Border Price. Compound growth rates were calculated based on Gujarati (1995) to examine the trends in fisheries trade. The econometric regression model was used to study the impact of fisheries exports on economic growth (Metwally, 1980). The regression model used was as follows,

$$
Y_{t}=b_{0}+b_{1} X_{t}+b_{2} X_{t-1}+b_{3} X_{t-2}
$$

Where: $Y_{t}-$ Value of Gross Domestic Product in year $(\mathrm{t})$

$X_{t}-$ Value of marine products exports in year (t) and first lag (t-1) \& second lag (t-2)

\section{Results and Discussion}

The value of export of marine products during the period 1995 to 2004 is presented in Table 1. The annual export value of the fisheries sector has remarkably increased from Rs.3,655.49 Million in 1995 to Rs.9,435.00 Million in 2004. There were wide fluctuations seen in the export of lobsters and fish. The share of prawns constituted about 67 percent of the export earning of fisheries sector in
1998, followed by earnings from export of ornamental fish. The share of exports of prawns had declined sharply during this period to 26 percent, while the share of export of fish had increased significantly to 47 percent by 2004 .

The extent of diversification in the export of fisheries products showed mixed trends. Table 2 indicates the HHI and SDI of commodity concentration rate for the period 1995-2004. Both indices reflected a declining trend during 1998 to 2004. Both the two estimates provide closely similar values, thus reflecting the degree of marine export products concentration pattern. Since 1999 the values of both indices started to decline, because they had relatively become more concentrated and less diversified. This means export earnings from fisheries products in Sri Lanka highly depends on one or a few commodities. The SDI for marine products exported fluctuated between 0.37 in 1995 to 0.30 in 2004. However, moderate export product diversity had occurred in 1998 when both the indices reached to the highest levels, which was 0.47 .

Table 2. Simpson Diversity Index (SDI) and Herfindhal-Hirschman Index (HHI) for exports of fisheries products (1995-2004)

\begin{tabular}{lllllllllll}
\hline Year & 1995 & 1996 & 1997 & 1998 & 1999 & 2000 & 2001 & 2002 & 2003 & 2004 \\
\hline SDI & 0.38 & 0.37 & 0.38 & 0.47 & 0.29 & 0.37 & 0.35 & 0.31 & 0.31 & 0.30 \\
HHI & 0.39 & 0.45 & 0.39 & 0.48 & 0.30 & 0.38 & 0.36 & 0.30 & 0.32 & 0.31 \\
\hline
\end{tabular}

(Source: Authors' estimates)

The compound growth rate was worked out to identify the rate of growth in marine products exports in terms of quantity and value of fisheries products. The annual growth rate of fisheries products exports in terms of quantity and value were 0.13 and 0.1 respectively. Both values indicated positive signs reflecting the increasing trend in fisheries exports. Figure 1 indicates the trends in export, import and net trade of fisheries product in Sri Lanka. This figure revealed that every year net trade value was positive because total fisheries exports exceeded total imports significantly. In year 2000 it reflected the highest net trade value in marine products exports after adjustment for the inflation.

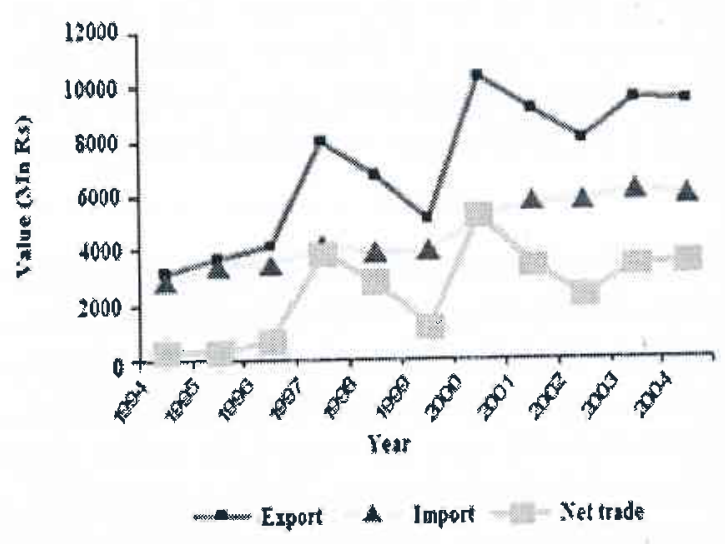

Figure 1. Value of Exports, Imports and Net trade of Fisheries products (1994-2004) 
Nominal Protection Coefficient (NPC) has been calculated to measure the export competitiveness of selected fisheries product such as prawns crabs and lobsters in the international market. Table 3 depicts NPC value of selected fisheries product in the international market. An examination of the NPC for different fisheries products indicated that all the goods were competitive internationally, because all the values in each year were less than unity. The result of the GISP export growth relationship was identified as follows,

$$
\begin{gathered}
\mathrm{Y}_{t}=212185+39.90 \mathrm{X}_{\mathrm{t}}+32.42 \mathrm{X}_{t-1}+57.52 \mathrm{X}_{i-2} \\
(76237)(16.79)(17.42)^{* * *}(15.81)^{* *} \\
\mathrm{R}^{2}=0.95, \text { Adj. } \mathrm{R}^{2}=0.93, \quad \mathrm{DW}=1.005, \mathrm{~F} \text { value }=45.73
\end{gathered}
$$

The results revealed that fisheries export value at the current period significantly explained current GDP, as shown by the value of t statisties of the coefficient of $X$ variable in the parenthesis. Both the first and second year lag export variables have a positive effect on the GDP growth during the study period. Both the coefficients of $\mathrm{X}_{\mathrm{t}-1}(\mathrm{P}<\mathrm{A} .1)$ and $X_{0-2}(P<0.05)$ variables were statisticaly significant.

Table 3. Nominal Protection Coefficient values -Marine Products (2000-2nens)

\begin{tabular}{llll}
\hline Year & Prawe & Lobsters & Crans \\
\hline 2000 & 0.86 & 0.98 & 0.91 \\
2001 & 0.89 & 0.96 & 0.95 \\
2002 & 0.85 & 0.91 & 0.89 \\
2003 & 0.86 & 0.95 & 0.90 \\
2004 & 0.87 & 0.92 & 0.90 \\
\hline
\end{tabular}

(Sourc: Anthor's sstinates)

\section{Conclusions and rolicy Implications}

The study showed that the compound growth rates of marine products export sector wer 0.13 and 0.1 percent in terms of value and quantity of exports respectively. Regression results revealed that marine products exports had marginally stimulated the growth of output in Sri Lanka. The diversity index values and concentration indices values show Sri Yanka fisheries export became more concentrated and less diversified. Within fisheries products prawns, lobsters and crabs, Sri Lanka was reasonably competitive in international market, this was revealed by calculating Nominal Protection Co-efficient values. The world demand for fisheries product consumption is increasing both because of incomes and population growth and also due to the substitution of fish in place of meat. Therefore, Sri Lanka needs to promote export of competitive fishery products to the world market to achieve high rate of economic growth in Sri Lanka. To achieve high growth rate it has to try to minimize the fluctuations in fisheries export earnings and wants to find out niche market for our fishery products and in the meantime we want to export value added fishery products instead of exporting raw products.

\section{Ranerares}

Bathrick, D. D. (1998). Fostering global well-being A new paradign to revidize foricuthat and rural development. Washagron, DC: International Food Policy Research Institute.

Biggs, T., M. Miller., C. Otto and O. Tyler (1996). Africa can compete: Export opportunities and challenges for garments and home products in the European market. Washington, DC: World Bank.

Customs of Sri Lanka, (1995-2004). External Trade Statistics Yearbooks, Srï Lanka Custom, Colombo, Sri Lanka.

Central Bank of Sri Lanka, (2004). Annual Repors, Central Bank of Sri Lanka, Colombo, Sri Lanka.

EDB, (2005). Export Performance Indicators 1995-2004, Policy Phaming Division, Export Development Board, Colombo 02, Sri Lanka.

Edwards, S. (1992). Trade orientation, distortions and growth in developing countries. Joumal of Development Studies, 39(1): $31-57$. 
ESCAP, (1996). Promoting exports of fish and fishery products in selected island developing countries of the ESCAP region. Economic and Social Commission for Asia and the Pacific. New York: United Nations.

Gujarati, D.N. (1995). Basic Econometrics. McGraw-Hall, New York. P.755.

Henson, S. and R. Loader. (2001). Barriers to Agricultural Exports from Developing Countries: The Role of Sanitary and Phytosanitary Requirements. World Development. 29 (1): 85-102, 2001; Elsevier Science Ltd.

Love, J. (1986). Commodity Concentration and Export Earnings Instability: a Shift from Cross-section to Time Series Analysis. Journal of Development Economics. 24: 239-248.
Metwally, M.M. and H.U. Tamaschke 1980; Oil exports and economic Growth in the Middle East, Kyklos. Blackwell Publishing. 33(3): p.499-522.

Milner, C. (1990). Export promotion strategies: Theory and evidence from developing countries. London: Harvester Wheatsheaf. UK.

Murphy, K. M. and A. Shleifer (1997). Quality and trade. Journal of Development Economics, 53: 1-15.

NARA, (2004). Sri Lanka Fisheries Year Book2004, National Aquatic Resources Research and Development Agency, Crow Island, Mattakkuliya, Sri Lanka. p. 92. 


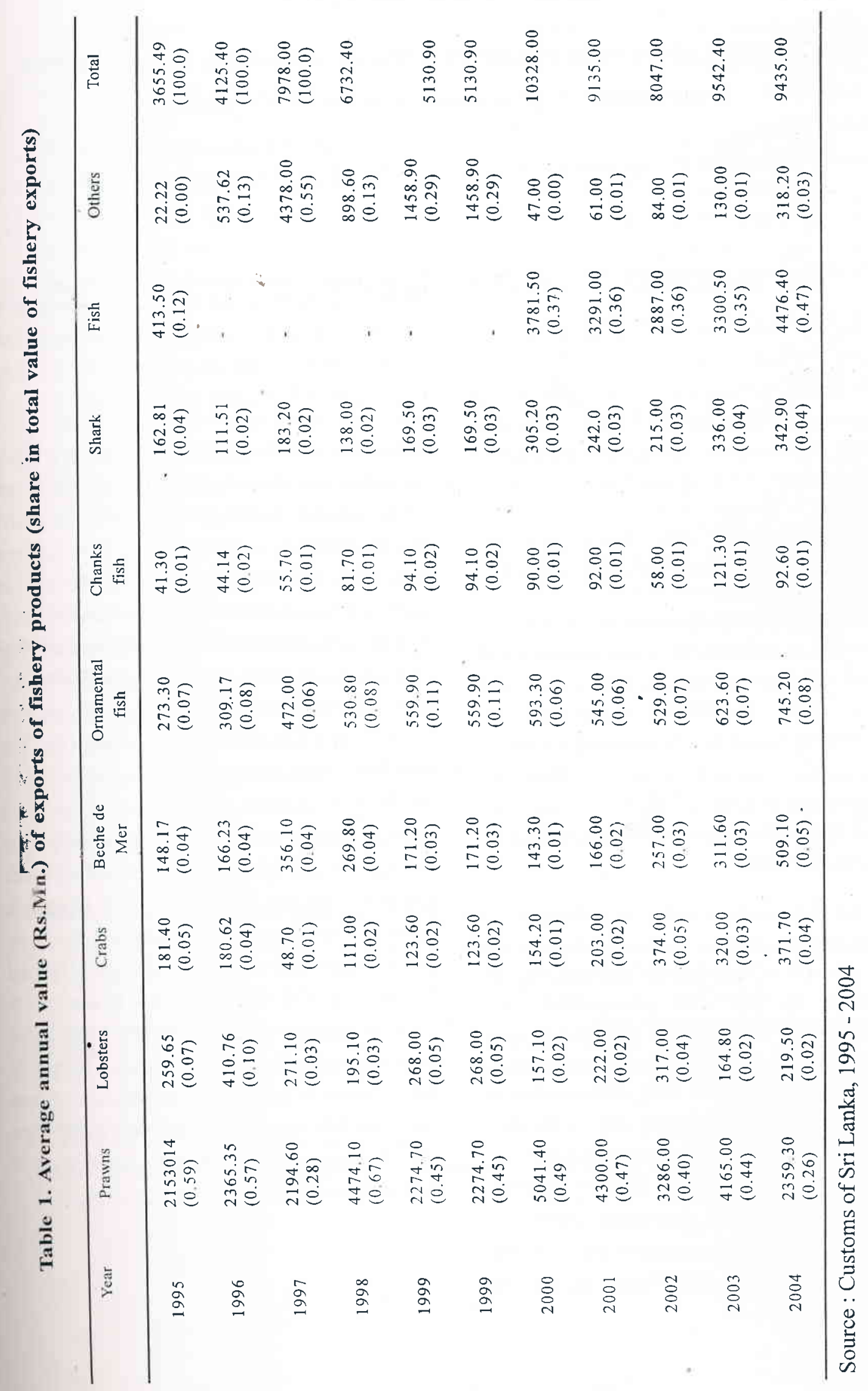

